press themselves. Reference librarians who wish the card catalog to answer every possible question without considering the consequences of their demands upon the catalog department have been responsible to a larger degree than has generally been believed for the development of what Osborn has termed legalistic, perfectionist, and bibliographical cataloging. Finally, library school instructors of cataloging who have failed to keep in touch with practice have continued to teach young librarians theory without serious attempts to instil in them the urge to examine their work on the basis of individual cases or from the standpoint of users.

\section{Publications Important}

The three publications under discussion, therefore, are important at this time when administrators and catalogers have begun to wonder seriously about cataloging rules and processes. The new edition of the A.L.A. Catalog Rules appears as a result of the demands for uniformity in practice. The development of cooperative cataloging and union catalogs undoubtedly has increased the pressure for a set of rules which would provide guidance on matters which were not in existence when the I 908 rules were compiled. The inclusion of a considerable number of examples seems particularly useful. Sensibly, acceptable variations in practice are noted. The fact that the volume contains so many details and rules does not discredit it. If librarianship is to be scientific at all, codification of rules and principles seems basic. Osborn actually indicts American catalogers when he implies that they are incapable of using intelligence in applying rules to practical needs.

It might be pointed out that the division of the new edition of the rules into two parts-I. Entry and Heading, and II. Description of Book-is a highly desirable feature. It is to be expected that library practice so far as entry and heading are concerned will be uniform. Practice in regard to the description of the books should undoubtedly vary.

The golden age of cataloging in its old sense may be over. But it is on the threshold of an interesting and challenging era. There can be but one conclusion to the present difficulties in cataloging so far as large libraries are concerned: increased and systematic cooperation and centralization. Administrators, catalogers, reference librarians, and teachers of cataloging will need to expend considerable thought on the problem if cataloging will meet the needs of users effectively and economically. And it is necessary to determine accurately just what the userspatrons and staff members-really require. Future numbers of the Catalogers' and Classifiers' Yearbook might well be devoted to a further discussion of these problems.-Maurice F. Tauber, University of Chicago Libraries.

Incunabula in American Libraries. Edited by Margaret Bingham Stillwell. Bibliographical Society of America, New York, I940: 8vo., xiv, 6ig p.

THE FIRST of anything exerts a strong appeal upon well-nigh everyone and the sentimental attraction seems often to be in inverse ratio to its current usefulness or even to the comprehension of those who are the most fervent worshippers at its shrine. Nothing has exemplified this more curiously than the books of the fifteenth century, long segregated in highly honored seclusion under the impressive caption of "incunabula." 
The book that marked the end of experimentation and the inauguration of the business of printing as a commercial craft was the so-called Gutenberg Bible, a weighty two-volume publication designed for use at church altars. Men who had had a hand in the production of that work were still actively engaged in making other and handier books when copies of the First Bible began to pass out of the churches into the possession of collectors who treasured it, not because they wanted to read it but because of the story that went with it. As a result of this contemporary interest among the laity rather than by the churchmen, there are nearly fifty copies of the First Bible whose stigmata are as carefully registered as those of blooded calves or pearls of great price. Other Bibles just as good, or better for actual use, were on the market while that original edition was still to be had at the publication price, but copies of these, which were in production before the first one had been completed, are now virtually unprocurable. There are a dozen copies of the First in American libraries. Three or four of these same institutions consider themselves fortunate in being able to exhibit a single leaf or two from the one that was probably second in date. That this is a normal situation is shown by the parallel case of the first book printed in English America, just a hundred years after printing began on the Western Hemisphere. There are eleven copies registered of that Bay Psalm Book; there are two copies of the second edition of 1647 and only one of the edition of 1651 .

Fifteenth century books were over a hundred years old when discriminating book collectors began, so far as can now be told, to pick and choose the cleanest copies of the oldest texts of the books they liked to read. They liked to fondle slightly old editions of Plutarch or Herodotus, of Aeschylus or Terence, with the same satisfactions that their spiritual progeny find in an untrimmed Endymion or Hiawatha "as issued." Until the Napoleonic era, incunabula continued to be the literary firsts for collectors who had been drilled at school and university on the Latin and Greek classics until they could catch an error in scansion or a false quantity in a quotation in a speech by a parliamentary colleague. After that, new men and new fortunes brought changes in the book market as in other lines of serious work and play. Halfway through the twentieth century, the chief of the patent department of the world's most embracive utility for relaxation reads

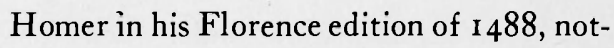
ing misprints and textual variations, but this is nowadays unusual. For most of the nineteenth century, the collecting of Fifteeners was the following of a tradition, the treasuring of curiosities of a long ago.

A hundred years ago now, college people and especially the librarians who found themselves in charge of considerable numbers of fifteenth century books, became uneasy over their inability to answer many of the questions that were being asked them, not about the contents but about other aspects of these ancient tomes. Most often these were questions as to who and when and where. Out of these grew a new science of book knowledge christened "bibliography." Two Englishmen had most to do with its upbringing.

William Blades, when he found that his printing business was in shape to take care of itself, turned his leisurely attention to composing a life of the first English printer, William Caxton. He read widely 
and visited archives in search of what could be found concerning his subject. More important, he looked at the actual books that carry Caxton's name with the critical eye of a master printer who had watched over the work that was being done in his own establishment. Noting that Caxton's work, like his own, sometimes revealed manufacturing tricks and slips, he went on to examine all the copies of the original publications that he could locate. As he went along, Blades not only kept careful memoranda of what he found, but he devised his own technical methods of describing the books to meet the needs that he was himself creating. These are far from satisfying the meticulous requirements of the science that has evolved since his day, but these later requirements are very largely developments from the model set by Blades. Most important of all, as a practical craftsman he recognized that everything depended on accurate observation and understanding of the material that Caxton's workmen had to work with, and primarily his type fonts.

\section{Henry Bradshaw}

Henry Bradshaw, librarian of Cambridge University, was steeped in the academic scholarship that Blades knew little about. Finding himself in charge of a large number of old books that were of very little use in the places where his predecessors had shelved them, he devised a new arrangement into which they could be grouped. This worked out into what he called the "natural history" method of classifying all fifteenth century books as examples of printing instead of by authors or subjects. As perfected by Robert Proctor at the British Museum, this rearranged all incunabula under the press at which each book was produced, in the order in which they appeared. The individual presses were grouped under the localities in which they belonged, in the chronological order in which the printer began working there. The several localities were similarly arranged chronologically under their country, and the countries in the order of the earliest printing in each. This brought order out of previous chaos. It became possible to understand how typography spread over the civilized world and how it influenced the economic practices and cultural development of the different nations.

\section{Study of Type Faces}

The scientific system worked perfectly as long as it dealt with precise data. The machinery clogged when its material was messed up by normal human factors. There are obviously different editions of the same work with identical place and date, and it is not always certain which copied the other. Very nearly half of all the extant fifteenth century publications do not carry any statement telling when or where they were produced. These provided the occasion for prolonged and amazingly fruitful comparisons of type faces. All the books that were printed with identical fonts were grouped together, even though there is sometimes no certainty as to where they were printed. An anonymous type not infrequently is found in a book that also contains a type used by a known printer to whom the foundling can then be assigned. This worked satisfactorily for a few years, until it came to be realised that in the fifteenth century, as in later centuries, men sometimes went out of business and disposed of their stock in trade without leaving any record of what had happened. 
The study of type faces absorbed the attention of incunabulists for more than two decades. The professionals were still deep in these researches when other investigators began reporting the results of a renewed hunt for fresh documentary evidence in the public archives. The names of printers were found of whose work nothing is known, and more confusingly some who paid taxes in one place at times when their names appear on books from another. The broadening interest that was evidenced by these activities had another even more disturbing effect on the placidity of the subject. The number of recorded incunabula multiplied three, four, perhaps five times. The new titles moreover were almost always more interesting in their contents as well as much rarer than those previously known, and the proportion of unidentifiable pieces was very much greater.

\section{Gesamtkatalog der Wiegendrucke}

Fifteenth century typography is a subject that has fascinated students who found occasion to look into it from early in the eighteenth century. It was compact, clean-cut, with a definite body of material that seemed fixed and, within reasonable comprehension, that could not be increased beyond the sum total already in existence within a limited area. By the end of the nineteenth century these advantages were breaking down. The limitations had broken bounds. Something had to be done. The German incunabulists, asserting their right to monopolise this German invention, undertook to bring the material under control. They proposed to prepare and publish a "Gesamtkatalog der Wiegendrucke" which should describe adequately every discoverable piece of fifteenth century typographic workmanship.
A special mission was sent to Italy to sift the contents of every big and little hiding place where these things might lurk. England and France had already begun a similar rounding up of their national holdings, and now dropped other bibliographical programs to expedite the larger undertaking. America did what it could by attempting to compile a census of copies in public and private collections. An enormous amount of data was accumulated at Berlin, and publication proceeded with the inevitable delays incidental to the thoroughgoing attempt to settle all the uncertainties for all time. Then came war, with the letter " $F$ " unfinished.

\section{Census of I9I9}

Shortly, another incunabular situation arose in America that asked for alleviation. The Census of Fifteenth Century Books Owned in America which was printed by the New York Public Library in 1919 had done its work almost too well. It had proved valuable as a union catalog of the principal collections, with a single important exception. It made it possible for students whose researches led them to these books to locate copies of the widely scattered titles. It stimulated interest and appreciation in the custodians of libraries, both those who had these books and those who lacked them. One such, Henry E. Huntington, saw the opportunity to gain distinction for his collection by making a determined attempt to secure whatever the book market offered that was not registered as being in any other American institution. The booksellers did what they could, and "No copy in America" became a commonplace in their catalogs, some of which listed not a single item that was to be found in the Census. 
Luckily, the impending need for a more careful second edition had been quickly foreseen by Margaret Bingham Stillwell. She had helped in the preparation of the Census of I9I9 and had gone on to the charge of the Rush C. Hawkins collection of First Books by the First Printers in the Annmary Brown Memorial at Providence. That special library of fifteenth century books was obviously the strategic place to establish a clearing house for information about American incunabula, and Miss Stillwell went about establishing her right to expect to be notified whenever an addition was made to any other collection. Eventually after many discouragements her foresighted persistence was rewarded. The Bibliographical Society of America, which had sponsored the first Census, secured the necessary funds to pay for assistance in completing the material. An advisory committee with Lawrence C. Wroth as chairman was appointed to stand back of Miss Stillwell and provide any needed support.

\section{Second Census}

The "Second Census" spread its net over Canada and Mexico as well as the United States. It is a volume of $\mathrm{xlv}$ and 6 I9 pages, listing 35,232 copies (about
13,200 in 1919 ) of $I I, I 32$ titles (6292 in 1919) in 332 public (173 in 1919) and 390 private (255 in 1919) collections.

That the work must go on, backed by some adequate financial support, is clear from the three pages of addenda, presenting information that arrived too late for inclusion at the proper place. It shows I08 additional copies for titles already entered, and twenty new titles not before available for American students. Fourteen entries record a significant gift to the Dartmouth College library. Seventeen other entries marked "change" are in the nature of errata, and look as if the responsibility might be evenly divided between the technical staff and the printer's compositor, Mr. Skillings, to whom the Preface pays a laboriously earned tribute. There are undoubtedly other errors in the eighty thousand lines of nondescript medieval Latin and tricky bibliographical contractions spiced with numberless meaningless figures, but there is every reason to believe that these will prove to be amazingly few. It is a volume that bids fair to become a landmark of American typographic craftsmanship as well as of scholarly standards and achievement.-George P. Winship. 